\title{
Restorative Justice in Cordillera Administrative Region: Tradition and Praxis towards a Peace Process Model
}

\author{
Joni L. Pagandian ${ }^{1} \&$ Jesster P. Eduardo ${ }^{2}$ \\ ${ }^{1}$ Associate Professor, College of Criminal Justice Education, Mt. Province Polytechnic College, Mt.Province, Philippines \\ ${ }^{2}$ Professor, College of Criminology, Nueva Ecija University of Science and Technology, Nueva Ecija, Philippines \\ Correspondence: Jesster Pasule Eduardo, Professor, College of Criminology, Nueva Ecija University of Science and \\ Technology, Nueva Ecija, Philippines.
}

Received: November 5, 2018

doi:10.11114/ijsss.v7i1.3748
Accepted: December 4, 2018 Available online: December 21, 2018

URL: https://doi.org/10.11114/ijsss.v7i1.3748

\begin{abstract}
The study assessed the peace processes under the concept of Restorative Justice in Cordillera Administrate Region (CAR). Restorative Justice (RJ) is a means to heal, not punish, the harm caused by one person to another. It is a process which allows the harmed party to participate in the decisions which are made to heal the harm caused them. The study used the Individual Positivism Theory to analyze the use of RJ in CAR. Through Descriptive Survey Method, the level of attainment of the goals and objectives of peace processes was measured based on the responses of the three groups of respondents in the study namely: (a) Stakeholders (victims, complainants, respondents, witnesses, and the community); (b) Barangay Peace and Order Council (BPOC) (Lupong Tagapamayapa chaired by the Punong Barangay [Barangay Officials] and Council of Elders); and (c) PNP organic personnel. Hence, study showed that RJ through indigenous method of conflict resolution played a significant role in preserving Unity, Peace and Order, and Justice in the community most especially among families, relatives, or clans in CAR.
\end{abstract}

Keywords: restorative justice, cordillera administrative region, tradition, peace process, indigenous peoples

\section{Introduction}

Justice is a human necessity. Similarly, Restorative Justice (RJ) is a need in criminal justice system in every country; thereby, staying away from old-fashioned justice practices which, at present, is objectionable or offensive to human sensibilities. Hence, the emergence, recognition, and adoption of RJ is an indubitable manifestation of development in criminal justice. RJ promotes recovery and healing that is ultimately the domain of not only the victim but also the parties involved in the crime. It maximizes opportunities for exchange of information, participation, dialogue and mutual consent between victim, offender and the community. These are strong manifestation of everyone's quest for justice due to backlog of cases in court dockets evidenced by "freezing the ball technique" in the dispensation of justice in courts. Of these, mediation or extra-judicial trial or settlement is being applied through the concept of RJ. This study centered on RJ in Cordillera Administrative Region (CAR), despite limited writings and studies related to restorative justice, the researchers offer the following literatures.

RJ policies and practices are being adopted around the world. In 2002, the United Nations Economic and Social Council (ECOSOC) defined Restorative process as any process in which the victim and the offender, and, where appropriate, any other individuals or community members affected by a crime, participate together actively in the resolution of matters arising from the crime, generally with the help of a facilitator. Restorative processes may include mediation, conciliation, conferencing and sentencing circles. Braithwaite (2004) viewed RJ as a process where all stakeholders affected by an injustice have an opportunity to discuss how they have been affected by the injustice and to decide what should be done to repair the harm. With crime, restorative justice is about the idea that because crime hurts, justice should heal. Also, Sherman and Strang (2007) said that RJ is a way of thinking about what is best for the many connections among crime victims, their offenders and the criminal justice process. RJ advocates suggest that conventional assumptions about these connections may be wrong: that victims should be at the center rather than excluded from the process, that victims and offenders are not natural enemies, that victims are not primarily retributive in their view of justice, that prison is not necessarily the best way to prevent repeat crime. On the same point, Boyes-Watson (2014) defined RJ as a growing social movement to institutionalize peaceful approaches to harm, problem-solving and violations 
of legal and human rights. RJ seeks to build partnerships to reestablish mutual responsibility for constructive responses to wrongdoing within our communities. Restorative approaches seek a balanced approach to the needs of the victim, wrongdoer and community through processes that preserve the safety and dignity of all. An RJ program aims to get offenders to take responsibility for their actions, to understand the harm they have caused, to give them an opportunity to redeem themselves and to discourage them from causing further harm. For victims, its goal is to give them an active role in the process (Parade, October 25, 2009).

The process of RJ within the context of United Nations ECOSOC has influenced its member countries. ECOSOC resolution in 2012 has encouraged its Member States to draw on the basic principles on the use of restorative justice programmes in criminal matters in the development and operation of restorative justice programmes. The 1987 Philippine Constitution declared that it is the policy of the State to promote social justice in all phases of national development (Art. II, Sec. 10). Also, the Constitution mandates the Supreme Court to promulgate rules that shall “...provide a simplified and inexpensive procedure for the disposition of cases... (Art. VIII, Sec. 5)." Moreover, the Parole and Probation Administration (2018) in the Philippines views RJ as a process through which remorseful offenders accept responsibility for their misconduct, particularly to their victims and to the community. It creates obligation to make things right through proactive involvement of victims, ownership of the offender of the crime and the community in search for solutions which promote repair, reconciliation and reassurance.

RJ plays an important role in today's criminal justice. Sherman (2003) mentioned that RJ is the prime but not only example of the recent trend towards a more "emotionally intelligent" approach to criminal justice. Zehr (2002) suggested that RJ requires society to move away from a system that emphasizes traditional retributive justice (an eye for an eye). Sherman (1993) believed that the doctrine that tougher punishment deters crime by making offenders fearful has been widely falsified for many kinds of offenders. Morrison and Vaandering (2012) argued that a system influenced by RJ would define "laws and rules as serving people to protect and encourage relationships and relational cultures" rather than protecting the status quo. Siegel and Senna (2007) emphasized that RJ is a view of criminal justice focusing on crime as an act against the community rather than the state. Whereby, advocates and/or promoters of such, come to a point of suggesting a policy based on: restoring the damage caused by crime, creating a system of justice which includes all parties harmed by the criminal act-victim, offender, community and/or society. Eskridge (2004) stressed that, in criminal justice, the practice of restorative justice could help in many ways. According to Goldkamp (1994), the earliest applications of RJ in the United States were in the criminal and juvenile justice systems. The first drug court created in 1989 in Miami commenced modern day restorative practices. Sherman and Strang (2007) stated that the implementation of RJ was proven to be effective through the use of peer support, counseling, and education, they became more widespread. The evidence of RJ's effectiveness within the justice system (Sherman \& Strang, 2007) has led for a call to implement RJ interventions on a broader scale, particularly for low-level crimes that are nonviolent, and for juveniles. In fact, New Zealand used RJ as a central framework in its juvenile justice system for nearly 25 years (Zehr, 2002). Studies in England found the vast majority of police organizations practice restorative techniques (Resolution 36, 2010).

Academic assessment of restorative justice is positive. Most studies suggest that it makes offenders less likely to reoffend. Sherman and Strang (2007) found that it had the highest rate of victim satisfaction and offender accountability of any method of justice. In criminal cases, victims can testify about the crime's impact upon their lives, receive answers to questions about the incident, and participate in holding the offender accountable. Meanwhile, offenders can tell their story of why the crime occurred and how it has affected their lives. They are given an opportunity to compensate the victim directly - to the degree possible (Zaibert, 2006). This can include money, community service in general and/or specific to the offense, education to prevent recidivism, and/or expression of remorse. A courtroom process might employ pretrial diversion, dismissing charges after restitution. In serious cases, a sentence may precede other restitution (Kaulike, 2014). In prisons, besides serving as an alternative to civil or criminal trial, restorative justice is also thought to be applicable to offenders who are currently incarcerated (Barb, 2006). The purpose of RJ in prison is to assist with the prisoner's rehabilitation, and eventual reintegration into society. By repairing the harm to the relationships between offenders and victims, and offenders and the community that resulted from the crime, restorative justice seeks to understand and address the circumstances which contributed to the crime. The potential for restorative justice to reduce recidivism is one of the strongest and most promising arguments for its use in prisons (Berit, 2011). In 2005, a pilot reentry program was developed in one of Hawaii's minimum-security prisons. This program's goal is to help inmates who are close to being released back into society through the use of restorative circles. The survey found that out of ninety-nine participants, ninety-three found it to be very positive, while only one person stated that it was negative. One of the main reasons for its positive outlook was that inmates were able to find out their strengths and that they had a support system to help guide them (Walker, Sakai, \& Brady, 2006). The use of incarceration breaks up families. An offender's child may develop a greater likelihood of committing a crime in the future (Blake, 2008). Karp and Breslin (2001) believe 
that one must improve community capacity to provide an offender with opportunities to succeed. Such opportunities include employment, community work, or further education. They also believe that success is dictated by a program that provides "clear norms and behavior standards." One of the last items required for success is to develop "social control, stress management, problem solving, and communication skills (Karp \& Breslin, 2001; Gottfredson, 1997).

Our government supports and adopts the concept of RJ. The Commission on Crime Prevention and Criminal Justice, of which the Philippines is a member-country, through a draft resolution, recommended to the ECOSOC of the United Nations Organization the adoption of the Basic Principles on the Use of Restorative Justice Programmes in Criminal Matters. In the police aspect, the country has a police force named Philippine National Police (PNP) that is a community and service-oriented agency responsible for the maintenance of peace and order and public safety (Eduardo \& Gabriel, 2017). Its vision for 2030 is to be a highly capable, effective and credible police service working in partnership with a responsive community towards the attainment of a safer place to live, work and do business. Hence, it also has its participation in the realization of RJ in the justice system. Similarly, the goal of the government is to establish a more enlightened and humane correctional system that will promote the reformation of offenders and thereby reduce the incidence of recidivism. This is in line with the applicable laws, rules, and policies mandating the Agency to administer the Parole and Probation System in the country. As such, the Parole and Probation Administration (PPA) is empowered to create innovative policies, programs, and activities to facilitate the reintegration of its clientele into the mainstream of society and consequently prevent the commission of crime. Therefore, PPA adopts RJ as one of its rehabilitation programs. It is worth to note that Former Department of Justice Secretary Leila De Lima during the National Summit on Collaborative Partnership Towards Enhancing the Dignity of Persons Deprived of Liberty in 2010 defined RJ as "a theory of justice that emphasizes on repairing the harm caused or revealed by criminal behavior." She mentioned that, "it is a goal and a big challenge down the road. One of the main obstacles to this goal was the tendency for each of the 5 pillars of the Philippine Criminal Justice System (law enforcement, prosecution, court, correction, and community) to work on its own. All of the institutions and actions in the criminal justice system are and should be interdependent. Our roles are interdependent, interconnecting and overlapping." She further said, "budgetary constraints for key agencies involved in the criminal justice system, and a lack of awareness at present on what restorative justice is, contribute to the difficulties" (ABS-CBN News, November 2010).

The country values the vital role of enabling laws in relation to RJ. Models in restorative justice within the court system include drug courts, domestic violence courts, and community courts (Goldkamp, 1994; Welsh \& Harris, 2008). In order to improve and make more effective the judicial system, the Katarungang Pambarangay (KP) Law was enacted in 1978 by virtue of Presidential Decree No. 1508, which is now known as Republic Act No. 7160 or the Barangay Justice System (BJS). It aims to establish a means of settling disputes amicably at the barangay level, so that the courts would be relieved of court congestion thereby enhancing the quality of justice dispensed by them. However, due to KP law's limitation on jurisdiction of cases, the practitioners anchored on the Indigenous Peoples' Rights Act (IPRA) or Republic Act No. 8371, anchored on the 1987 Philippine Constitution which states that, "Cultural communities have the right to use their own commonly accepted judicial system, conflict resolution processes that are compatible to the legal system of the country." Interestingly, Cordillera Administrative Region (CAR) is known to adopt indigenous modes of dispute resolution relying heavily on RJ such as the Bodong system among others. However, Eduardo (2018) found out that there is a negligible awareness on the context of IPRA of 1997.

The Philippines is one of the first countries in Asia recognizing the distinctive existence of indigenous peoples (Gabriel \& Mangahas, 2017). Restorative justice has its roots in a number of indigenous cultures, embracing traditions of 'spirituality' and holistic healing, and aiming to reconnect the offender with his/her environment and community (Sharpe, 1998). Many of the ideals of peace circles and restorative justice developed from indigenous practices throughout the world. A common practice among Native Americans includes the use of victim to offender meetings to resolve issues. The Lakota and Dakota peoples use a mixture of community conferencing and peace circles to bring together their community (Gehm, 1998). When a disruption has taken place within their community, the elders bring both victim and offender together into a circle consisting of one to two elders, and other members of the tribes. The elder discusses the impact of the disruption on the community both symbolically and materially (Gehm, 1998). The Maori in New Zealand also have similar practices with an emphasis on children and their value in the family. While such practices were nearly wiped out during colonization they have resurfaced and were successfully adopted and expanded at the state level in New Zealand to include juvenile delinquents and the development of a special police unit. The United States has adopted some of the aspects of this practice, as well (Morris \& Maxwell, 1998). In the country, laws exemplifying restorative justice as a means to address the problems confronting the criminal justice system are the Republic Act No. 10389 (An Act Institutionalizing Recognizance as a Mode of Granting the Release of an Indigent Person in Custody as an Accused in a Criminal Case and for other Purposes) and Republic Act 9344 (Juvenile Justice and Welfare Act [JJWA]) as amended by Republic Act 10630. The concept employed in the JJWA is far-removed from 
the traditional form and system of dispensation of justice and punishment. The law adopted the spirit of RJ, that is, the main aim of the law is not to punish youthful offenders but to device a way to reintegrate the erring juvenile individual back into society as a responsible, valuable and reformed person. Despite having embraced the concept of RJ in the country, protracted trials, prolonged resolution of cases, lack of legal representation, lack of judges, inability to post bail bond, congestion in jails, and lack of opportunity to reform and rehabilitate offenders still exist. This fissure between the ideal legal concept and actual situation encouraged the researchers to conduct a study on the Restorative Justice in the Cordillera Administrative Region: Tradition and Praxis Towards a Peace Process Model. The study contends that the inability of some concerned government personnel in the pillars of Philippine Criminal Justice System to maintain the performance of their mandated functions emanates from their failure to assert or non-observance on the laws with RJ interests. Hence, peace process under the belief of RJ shall be measured in terms of the degree of attainment which is critical to identify and improve the efficiency of concerned government officers. The study, therefore, posed the following problems, to wit:

1. How do the three groups of respondents assess the level of attainment of the goals and objectives of Restorative Justice in the Cordillera Administrative Region (CAR), in terms of Unity?

2. How do the three groups of respondents assess the level of attainment of the goals and objectives of Restorative Justice in the Cordillera Administrative Region (CAR), in terms of Peace and Order?

3. How do the three groups of respondents assess the level of attainment of the goals and objectives of Restorative Justice in the Cordillera Administrative Region (CAR), in terms of Justice?

\section{Methodology}

\subsection{Conceptual Framework}

The concept of this study is anchored on the belief that RJ is a means to heal, not punish, the harm caused by one person to another. It is a process which allows the harmed party to participate in the decisions which are made to heal the harm caused them. At the same time, the party doing the harm takes direct responsibility for their harming actions, is present, and takes part in the healing. The method also includes those who surround the parties directly involved. Their part in the process is to help in deciding a fair, acceptable and accomplishable healing of the harm, as well as what would be logical to help the harming party return to full acceptance by the community (Termotto, 2007). In the same vein, RJ is the deliberate opportunity for offender and victim to restore their relationship, along with a chance for the offender to come up with a means to repair the harm done to the victim..." (Mirsky, 2003). Similarly, McCold (1996) recorded that RJ has four principles: (a) moralizing, (b) healing, (c) empowering, and (d) transforming.

\subsection{Theoretical Framework}

The study is based on the individual positivism theory. Under the individual positivism, crime arises because the offender has not been sufficiently or effectively socialized, or 'schooled' in society's values. Crime or deviance is caused by the under-socialization of the individual: this may be due to innate factors (the person is incapable), the family's ineffectiveness in providing proper socialization, or to wider (social) influences. Behavior is seen as determined by the person's antecedents and, therefore, the policy to be followed is one where offenders are treated, rather than punished. For those who are incapable of achieving a satisfactory level of socialization, treatment may be replaced by containment. Although RJ and individual positivism are not entirely at peace with each other - the determinism of positivism lies uneasily with the emphasis within RJ on personal responsibility, both theories view on social order are similar. They define crime in a similar 'social' way and they both aim to 'reintegrate' offenders. This can be observed in the following statement about the aims of RJ: Mediation encourages offenders to: (a) own the responsibility for their crime, (b) become more aware of the effect of their crime on the victim, (c) reassess their future behavior in the light of this knowledge, and (d) apologize and/or offer appropriate reparation (Mediation UK, 1993).

Figure 1 shows the relationship between variables. By using the systems model, the study considered RJs goals and objectives in CAR in terms of Unity, Peace and Order, and Justice. These are inputs in the study that were considered in order to identify the level of attainment or degree of realization of RJ. The Process is the course of action undertaken to arrive at the output. Part of the output is of course the recommendation necessary to improve the delivery of RJ in CAR which could be in the form of training, seminar-workshop, and other approaches of learning. 


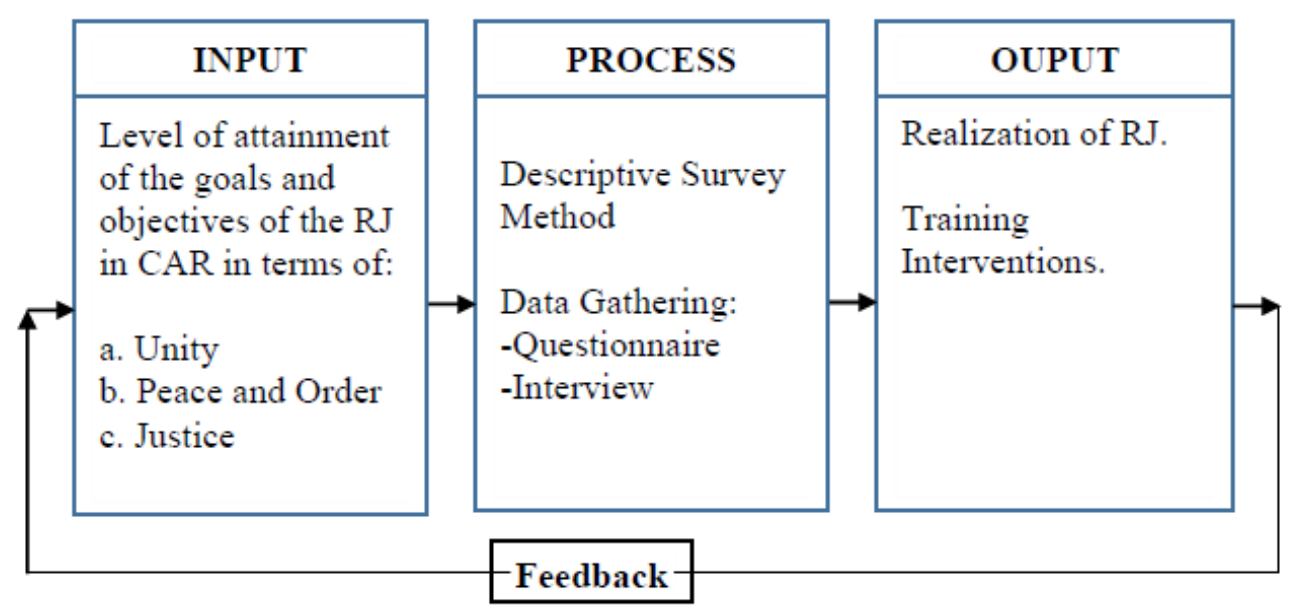

Figure 1. Research Paradigm

\subsection{The Research Locale}

The research study focused on the six (6) provinces to include the two (2) cities in the Cordillera Administrative Region, namely: Abra (tinggian tribe [itneg, binongan]), Apayao (isneg tribe [isnag, apayao]), Benguet (kankanaey, iyaplay, bontoc, ibaloi [ibaloy, nabaloi], and karao [karaw] tribes ), Ifugao (ifugao [ifugaw, ipugao, yfugao], and kalanguya [ikalahan]), Kalinga (with Tabuk City) (kalinga [limos, limos-liwan kalinga]) and Mountain Province (kankanaey, iyaplay, and bontoc tribes) as well as Baguio City as the regional center. Igorot (people of the mountains) is the mainstream, collective name of several of the tribes in the Cordilleras. The various indigenous groups are spreadout through the Cordillera (Philippines: Indigenous Peoples of Luzon/The Cordilleras, 2018).

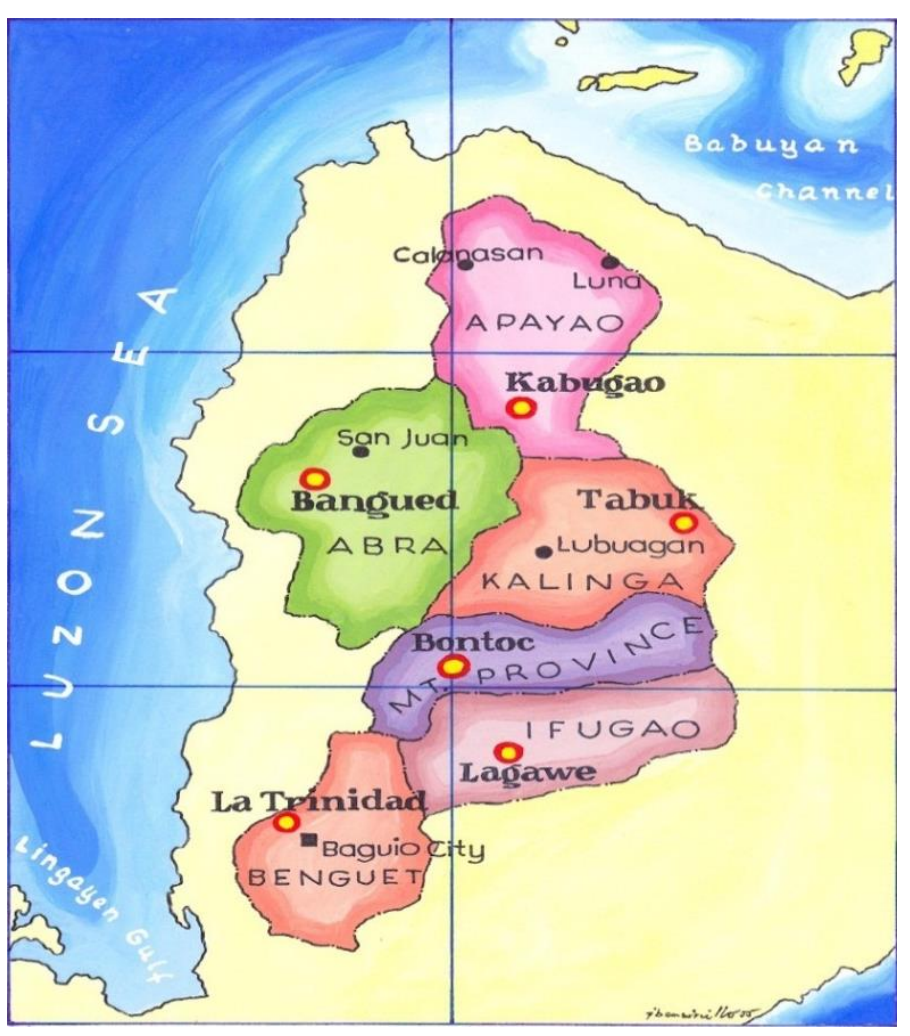

Figure 2. Map of Cordillera Administrative Region

As a physical region, the Cordillera - Gran Cordillera Central, to be complete - is a row of great mountain ranges occupying half of Northern Luzon in the Philippines. Its rugged mountainous backbone contains many peaks exceeding 2,000 meters in height, with rolling hills and stretches of river valleys along its flanks. Around $230 \mathrm{~km}$ long and $120 \mathrm{~km}$ wide, with an irregular shape, the mountainous region's estimated total area is about 17,500 square $\mathrm{km}$. The Cordillera is both the highest and the single largest mass of mountains in the entire Philippine archipelago (Cordillera Peoples Alliance, December 2006). 


\subsection{Research Design}

The study used the Descriptive Survey Method. This method involves the collection of data in order to test hypotheses or answer questions. According to Kumar (2014), this method can systematically describe a situation, problem, phenomenon, service or programs, or provides information or describes the attitude towards an issue.

\subsection{Data Gathering Procedure}

There were three groups of respondents in this study with a total of 300 equally distributed. They were grouped as follows: (a) Stakeholders (victims, complainants, respondents, witnesses, and the community); (b) Barangay Peace and Order Council (BPOC) (Lupong Tagapamayapa chaired by the Punong Barangay [Barangay Officials] and Council of Elders); and (c) PNP organic personnel with the permission of the National Commission on Indigenous Peoples Provincial Directors and respective heads of the respondents. Triangulation method was used. The respondents answered the same set of questionnaire-checklist (Appendix A) as the main instrument that consisted indicators on the Level of Attainment of the Goals and Objectives of the Restorative Justice in the CAR in terms of Unity, Peace and Order, and Justice. Interview and focused group discussion with groups of respondents was conducted and its results were considered in processing data. The researchers used the Simple Random Sampling method to extract the number of respondents. The respondents were offered five options from which to select responses and descriptors (Tables 1 and 2).

Table 1. Response mode on the level of attainment of the goals and objectives

\begin{tabular}{ccc}
\hline Index & Semantic differential & Verbal description \\
\hline 5 & Always & Carried out to a full extent. \\
4 & Very often & Carried out to a good extent. \\
3 & Often & Carried out to a fairly good extent. \\
2 & Rarely & Carried out to a very poor extent. \\
1 & Never & Never carried out. \\
\hline
\end{tabular}

Table 2. Descriptors on the level of attainment of the goals and objectives

\begin{tabular}{cccl}
\hline Rating & Limit of Index & Semantic Differential \\
\hline 5 & $4.21-5.00$ & Very Much Attained (VMA) \\
4 & $3.41-4.20$ & Much Attained (MuA) \\
3 & $2.61-3.40$ & Moderately Attained (MoA) \\
2 & $1.81-2.60$ & Less Attained (LA) \\
1 & $1.00-1.80$ & Not Attained (NA) \\
\hline
\end{tabular}

2.6 Reliability of the Instrument

The questionnaire-checklist was tested using ten (10) Stakeholders, ten (10) Barangay Peace and Order Council and Council of Elders, and ten (10) PNP organic personnel who are not respondents in the study and it was found reliable using Cronbach's Alpha. Experts in the field were also consulted such as the head of the Peace and Order Council, Indigenous Peoples Center, Mediators and Tribal Leaders.

\subsection{Statistical Tools}

Data were treated with the use of percentage method, weighted mean, and ranking,

\section{Results and Discussion}

3.1 The Attainment of the Goals and Objectives of the Peace Processes in the Concept of Restorative Justice in CAR in terms of Unity.

Table 3 shows that Stakeholders, PNP, and BPOC got an Overall Means Per Group of Respondents of 4.31, 4.61, and 4.28, respectively, interpreted as Very Much Attained. This means that all groups of respondents always carry out to the full extent the peace process under the framework of restorative justice in pursuance of unity. Also, each group of respondents profoundly perceives that restorative justice in CAR improves and creates unity in the community. 
Table 3. Restorative justice in car in terms of unity

\begin{tabular}{|c|c|c|c|c|c|}
\hline Indicator & A & B & $\mathrm{C}$ & $\begin{array}{c}\text { Overall } \\
\text { Mean }\end{array}$ & Rank \\
\hline $\begin{array}{l}\text { 1. Preservation of the long-time honored tradition of Filipinos that is close } \\
\text { family ties. }\end{array}$ & 4.38 & 4.76 & 4.44 & 4.53 & 1 \\
\hline $\begin{array}{l}\text { 2. The peace processes promote changes and provide opportunity to the } \\
\text { community to prevent similar harm from happening to others by resolving } \\
\text { their own conflict. }\end{array}$ & 4.32 & 4.91 & 4.30 & 4.51 & 2 \\
\hline $\begin{array}{l}\text { 3. Sustained cooperation, trust, togetherness in crime busting within the } \\
\text { community. }\end{array}$ & 4.28 & 4.59 & 4.23 & 4.37 & 7 \\
\hline $\begin{array}{l}\text { 4. Increased zeal and dedication, honesty and integrity among the peace } \\
\text { pact holders of every tribe. }\end{array}$ & 4.30 & 4.36 & 4.26 & 4.31 & 3 \\
\hline 5. Accountability for successes and failures. & 4.28 & 4.52 & 4.28 & 4.36 & 5 \\
\hline 6. Everyone is involved in some ways of helping others. & 4.31 & 4.41 & 4.35 & 4.36 & 4 \\
\hline $\begin{array}{l}\text { 7. Helps develop global concern on the retrogressing effect of justice } \\
\text { system. }\end{array}$ & 4.28 & 4.72 & 4.12 & 4.37 & 6 \\
\hline Overall Mean Per Group of Respondent & 4.31 & 4.61 & 4.28 & 4.40 & \\
\hline
\end{tabular}

Legend: A-Stakeholders $B$ - PNP C-BPOC

Visibly, the Preservation of the long-time honored tradition of Filipinos that is close family ties ranked $1^{\text {st; }}$ The peace processes promote changes and provide opportunity to the community to prevent similar harm from happening to others by resolving their own conflict ranked $2^{\text {nd; }}$ and Increased zeal and dedication, honesty and integrity among the peace pact holders of every tribe ranked $3^{\text {rd }}$ with Overall Means of 4.53, 4.51, and 4.31, respectively, all interpreted as Very Much Attained. It signifies that it was carried out to a full extent. Further, it implies that the three groups of respondents perceive and believe that RJ aids in the attainment of Unity. In the same vein, Boyes-Watson (2014) said that restorative justice as a growing social movement to institutionalize peaceful approaches to harm, problem-solving and violations of legal and human rights. Restorative justice seeks to build partnerships to reestablish mutual responsibility for constructive responses to wrongdoing within our communities. Restorative approaches seek a balanced approach to the needs of the victim, wrongdoer and community through processes that preserve the safety and dignity of all. Likewise, Mirsky, (2003) firmly believed that RJ is the deliberate opportunity for offender and victim to restore their relationship, along with a chance for the offender to come up with a means to repair the harm done to the victim... Dialogue with the respondents also disclosed that other than close family ties that keep unity, acceptance of Christian faith has contributed too in preserving unity despite being victimized.

\subsection{The Attainment of the Goals and Objectives of the Peace Processes in the Concept of Restorative Justice in CAR in terms of Peace and Order}

Table 4 shows that all groups of respondents viewed that RJ in CAR in terms of Peace and Order is Very Much Attained with Overall Means Per Group of Respondents of 4.68, 4.33, and 4.26 for Stakeholders, PNP, and BPOC, respectively. This implies that every group of respondents firmly observes that peace processes within the outline of RJ in CAR in terms of peace and order is always carried out to the full extent. Likewise, it signifies that each group of respondents has a strong sense of belief on the peace and order cause and effect of RJ.

Table 4. Restorative justice in car in terms of peace and order

\begin{tabular}{|c|c|c|c|c|c|}
\hline Indicator & A & B & $\mathrm{C}$ & $\begin{array}{c}\text { Overall } \\
\text { Mean }\end{array}$ & Rank \\
\hline $\begin{array}{l}\text { 1. Every member of the community is encouraged, especially the } \\
\text { complainant and the offender to value the decision of the council of elders } \\
\text { and/or peace pact holders. }\end{array}$ & 4.86 & 4.41 & 4.39 & 4.55 & 1 \\
\hline $\begin{array}{l}\text { 2. Every member of any tribe may transact business secure and safe within } \\
\text { the region without fear of revenge or retaliation from warring groups or } \\
\text { tribes. }\end{array}$ & 4.83 & 4.29 & 4.27 & 4.46 & 2 \\
\hline $\begin{array}{l}\text { 3. The peace processes foster emotional growth and development in a social } \\
\text { environment. }\end{array}$ & 4.65 & 4.35 & 4.21 & 4.40 & 3 \\
\hline $\begin{array}{l}\text { 4. Create an atmosphere where freedom of thought is nurtured and } \\
\text { encouraged. }\end{array}$ & 4.62 & 4.29 & 4.11 & 4.34 & 5 \\
\hline $\begin{array}{l}\text { 5. Intermarriage is encouraged between and among the members of } \\
\text { different tribes. }\end{array}$ & 4.42 & 4.33 & 4.33 & 4.36 & 4 \\
\hline Overall Mean Per Group of Respondent & 4.68 & 4.33 & 4.26 & 4.42 & \\
\hline
\end{tabular}

Legend: A-Stakeholders $\quad B-P N P \quad C-B P O C$

However, it is crystal clear that groups of respondents have confidence that peace and order through RJ is strongly attained based on the following results, to wit: Every member of the community is encouraged, especially the complainant and the offender to value the decision of the council of elders and/or peace pact holders ranked $1^{\text {st }}$; Every 
member of any tribe may transact business secure and safe within the region without fear of revenge or retaliation from warring group or tribe ranked $2^{\text {nd }}$; and The peace processes foster emotional growth and development in a social environment ranked $3^{\text {rd }}$ with an Overall Means of 4.55, 4.46, and 4.40, respectively, all interpreted as Very Much Attained. It means that it was exhibited to a full degree. It further infers that Stakeholders, PNP, and BPOC are satisfied and convinced that RJ in CAR is a practice that improves the status of peace and order especially that all groups of respondents greatly value and respect the verdicts of council of elders and/or peace pact holders. In support of the findings, Sharpe (1998) said that restorative justice has its roots in a number of indigenous cultures, embracing traditions of 'spirituality' and holistic healing, and aiming to reconnect the offender with his/her environment and community. Indigenous justice practices and philosophies have been important in the development of restorative justice processes such as conferencing and circles. Resolving conflicts in the country, especially concerning Indigenous peoples is done by enhancing traditional systems. In the same way, Mangangey (2005) claimed that indigenous peace processes though tedious in nature are preferred by the communities in the Cordillera Administrative Region because they serve as a deterrent factor in the commission of crimes. Finally, Hagemann (2003) claimed that using punishment in the form of isolation, detention or suspension to address behavioral problems in schools only aggravates other issues, such as bullying, violence, substandard academic performance, the lack of parental involvement, high staff turnover and burnout. Meanwhile, restorative practices are proving to be an effective alternative to punitive measures. Restorative measures are proving to be an effective means of preserving peace and order. Also, discussion with the respondents (BPOC) revealed that mediation or conciliation makes the offenders confess to crimes they commit in order to swiftly maintain peace in the community.

\subsection{Attainment of the Goals and Objectives of the Restorative Justice in the Cordillera Administrative Region in Terms of Equality and Equity (Justice)}

Table 5 presents that all groups of respondents perceived that justice is attained through the practice of RJ in CAR with Overall Means Per Group of Respondents of 4.29, 3.94, and 3.34 for the Stakeholders, PNP, and BPOC, respectively, all interpreted as Very Much Attained. This indicates that the practice of RJ in the pursuit of justice in CAR is realized to the full extent.

Table 5. Restorative justice in the car in terms of equality and equity (justice)

\begin{tabular}{|c|c|c|c|c|c|}
\hline Indicators & A & B & $\mathrm{C}$ & $\begin{array}{l}\text { Overall } \\
\text { Mean }\end{array}$ & Rank \\
\hline $\begin{array}{l}\text { 1.Assurance of fairness, not by uniformity of outcomes, but through } \\
\text { provision of necessary support and opportunity to all parties and avoidance } \\
\text { of discrimination based on ethnicity, class and sex. }\end{array}$ & 4.36 & 4.02 & 3.54 & 3.97 & 2 \\
\hline 2.Opportunities are provided for remorse, forgiveness and reconciliation. & 4.44 & 4.32 & 3.28 & 4.01 & 1 \\
\hline $\begin{array}{l}\text { 3.The peace processes always consider the value of reformation over } \\
\text { complaint behavior avoiding the loss of respect to human dignity. }\end{array}$ & 4.26 & 4.00 & 3.09 & 3.78 & 8 \\
\hline $\begin{array}{l}\text { 4.The peace processes uphold and preserve justice through maximized } \\
\text { opportunities for exchange of information, participation, dialogue and } \\
\text { mutual consent between victim and offender. }\end{array}$ & 4.33 & 3.76 & 3.41 & 3.83 & 4 \\
\hline 5.Provision of restitution on the part of the victim. & 4.43 & 3.70 & 3.37 & 3.83 & 5 \\
\hline 6.Offenders are supported and treated with respect and dignity. & 4.26 & 3.85 & 3.17 & 3.76 & 3 \\
\hline $\begin{array}{l}\text { 7. The peace processes monitor and encourage follow-through since } \\
\text { healing, recovery, accountability and change are maximized when } \\
\text { agreements are kept. }\end{array}$ & 4.22 & 3.72 & 3.37 & 3.77 & 7 \\
\hline 8.Rights, privileges and freedom are exercised by any member of the tribe. & 3.98 & 4.13 & 3.50 & 3.87 & 6 \\
\hline Overall Mean Per Group of Respondents & 4.29 & 3.94 & 3.34 & 3.85 & \\
\hline
\end{tabular}

Legend: A-Stakeholders; $B-P N P ; C$ - BPOC

Based on the result, each group of respondents perceives that Opportunities are provided for remorse, forgiveness and reconciliation ranked $1^{\text {st; }}$ Assurance of fairness, not by uniformity of outcomes, but through provision of necessary support and opportunity to all parties and avoidance of discrimination based on ethnicity, class and sex ranked $2^{\text {nd }}$, and Offenders are supported and treated with respect and dignity ranked $3^{\text {rd }}$ with an Overall Means of 4.01, 3.97, and 3.76, respectively, all interpreted as Very Much Attained. It suggests that all groups of respondents have faith that the aforesaid indicators are being practiced to the full degree. Hence, they agree that RJ aids in the attainment of justice. In connection therewith, interview with PNP disclosed that mediation is beneficial in the immediate dispensation of justice but, few of the respondents observed that one of its disadvantages is that sometimes it is not being honored by the parties because according to them (parties) mediation or extra-judicial settlement of disputes causes recidivism. More so, in the study of Parlade (2004), he noted that some of the disadvantages of mediation are: "Mediation does not always result in a settlement agreement" and "Mediation lacks the procedural and constitutional protections guaranteed by the judicial system". Also, Kim (2012) said that it has been consistently suggested by several studies that RJ can be most 
effective and its objectives could be attained if it is introduced at pre-charge stage before the commencement of official judicial proceedings. This means that RJ is best attained if it is practiced when the case is not yet at the prosecutor or court level. Based on the interview of stakeholders (victims), a small number of them felt that their respective offenders should have been imprisoned. However, they just can't resist or defy the decision of the Council of Elders; hence, their only option is to go with restitution. In the course of time, they gradually accept that forgiving their aggressors is the essence of justice.

\section{Conclusion}

The study showed that the people (groups of respondents) in CAR are not only conscious about RJ but they had been practicing it long time ago through indigenous means of settling dispute or conflict resolution and other means provided by Philippine laws. People in CAR mostly understand the concept and importance of RJ and favored it more than resorting to regular justice process. RJ through indigenous method of conflict resolution played a significant role in preserving Unity, Peace and Order, and Justice in the community most especially among families, relatives, or clans. The study also exhibited that Unity, Peace and Order, and Justice is also treasured and respected by the indigenous peoples in CAR; hence, they resort to RJ which uses more humanitarian, public-spirited and positive approach. Finally, the remarkable and commendable display or observance of RJ in CAR is shaped not only by its long years of practice but due to the deep sense of treasuring solidity in the community; most importantly, CAR is the land of various tribes, respect to tribal leaders or elders (that has "authority" over the people in the community) is a virtue and must be strictly observed. Tribal leaders or elders always decide for the benefit of the tribe principally in terms of solidarity and preserving peace. Tribal leaders or elders, being part of the body that conducts extra-judicial settlement of criminal/civil cases, conflict resolution, or mediation, make RJ work successfully in CAR.

\section{References}

1987 Philippine Constitution, Article II, Section 10.

1987 Philippine Constitution, Article VIII, Section 5.

A New Kind of Criminal Justice, Parade, October 25, 2009, p. 6.

Basic principles on the use of restorative justice programmes in criminal matters. ECOSOC Resolution 2002/12, Par. 2, $37^{\text {th }}$ Plenary Meeting. July 24, 2002.

Blake, D. (2008). Red hook justice: Discussion guide. The Reentry National Media Outreach Campaign. Retrieved from http://www.reentrymediaoutreach.org/pdfs/redhook_discussion.pdf

Boyes-Watson, C. (2014). Suffolk University, College of Arts \& Sciences, Center for Restorative Justice.

Braithwaite, J. (2004). Restorative justice and de-professionalization. The Good Society, 13(1), 28-31. https://doi.org/10.1353/gso.2004.0023

Eduardo, J. (2018). Indigenous Peoples' Rights Act (IPRA) Of 1997: A Standpoint from Selected Higher Education Institutions in Nueva Ecijaafter 20 Years. Journal of Progressive Research in Social Sciences (JPRSS), 8(1).

Eduardo, J., \& Gabriel, A. (2017). Assessing the leadership skills of the chiefs of police in the towns of Nueva Ecija, Philippines: A dichotomy between managerial competence and decision making ability. Open Journal of Leadership, 6(4). https://doi.org/10.4236/oj1.2017.64011

Eskridge, W. C. (2004). Criminal justice concept and issues. An Anthology Roxbury Publishing Company Los Angeles, California.

Figure 2: www.pixshark.com, Copyright @ 2018.

Gabriel, A. \& Mangahas, T. (2017). Indigenous People's Contribution to the Mitigation of Climate Variation, Their Perception, and Organizing Strategy for Sustainable Community Based Forest Resources Management in Caraballo Mountain, Philippines. Open Journal of Ecology, 7(2). https://doi.org/10.4236/oje.2017.72007

Gehm, J. R. (1988). Victim-offender mediation programs: An exploration of practice and theoretical frameworks. Western Criminology Review, 1(1). Retrieved from http://wcr.sonoma.edu/v1n1/gehm.html

Goldkamp, J. (1994). Miami's treatment drug court for felony defendants: Some implications of assessment findings. The Prison Journal, 73(2). https://doi.org/10.1177/0032855594074002002

Gottfredson, D. (1997). School-based crime prevention. In L. W. Sherman, D. Gottfredson, D. MacKenzie, J. Eck, P. Reuter, \& S. Bushway (Eds.), Preventing crime: What works, what doesn't, what's promising: A report to the United States Congress. College Park: University of Maryland.

Hagemann, O. (2003). Restorative justice in prison. Willan Publishing. 
Karp, D. R., \& Breslin, B. (2001). Restorative justice in school communities. Youth Society, 33(2). https://doi.org/10.1177/0044118X01033002006

Kaulike, P. (2014). A Hawaii criminal court provides restorative justice practices for healing relationships. Uscourts.gov. Archived from the original on 2015-03-01.

Kim, H. K. (2012). National crime prevention strategies and Asian model of crime prevention model KIC, Republic of Korea.

Kumar, R. (2014). Research methodology: A step-by-step guide for beginners ( $4^{\text {th }}$ ed.) SAGE. CA: Thousand Oaks.

Mangangey, Sr. R. L. (2005). Peace processes in Mountain Province: An analysis (Unpublished doctoral dissertation). Benguet State University, La Trinidad, Benguet, Province.

McCold, P. (1996). Restorative justice Delphi process round 3, Bethlehem, Pennsylvania: The Working Party on Restorative Justice of the Alliance of NGOs on Crime Prevention and Criminal Justice of the United Nations.

Mirsky, L. (2003). Albert Eglash and creative restitution, restorative practices. E-Forum. Retrieved from http://www.realjustice.org/library/eglash.html

Morris, A., \& Maxwell, G. (1998). Restorative justice in New Zealand: Family group conferences as a case study. Western Criminology Review, 1(1). Retrieved from http://wcr.sonoma.edu/v1n1/morris.html

Morrison, B., \& Vaandering, D. (2012). Restorative justice: Pedagogy, praxis, and discipline. Journal of School Violence, 11(2), 138-155. https://doi.org/10.1080/15388220.2011.653322

Parlade, C. O. (2004). The alternative dispute resolution Philippines. Rex Bookstore Incorporated.

Philippines: Indigenous Peoples of Luzon/The Cordilleras. University of Hawai'i at Mānoa. Retrieved from https://guides.library.manoa.hawaii.edu/c.php?g=105238\&p=687381

Presidential Decree No. 1508. An Act Establishing a System of Amicably Settling Disputes at the Barangay Level. June 11, 1978.

Reformina, I. (Reporter). (2010, November 16). Replacing punitive justice with restorative justice. ABS-CBN News. 2-day National Summit on Collaborative Partnership Towards Enhancing the Dignity of Persons Deprived of Liberty. Retrieved from http://news.abs-cbn.com/-depth/11/16/10/replacing-punitive-justice-restorative-justice

Republic Act 9344. Juvenile Justice and Welfare Act (JIWA) of 2006. April 28, 2006.

Republic Act No. 10389. An Act Institutionalizing Recognizance as a Mode of Granting the Release of an Indigent Person in Custody as an Accused in a Criminal Case and for other Purposes. March 14, 2013

Republic Act No. 7160. An Act Providing for a Local Government Code of 1991. October 10, 1991. Amended by RA 8553. February 25, 1998.

Republic Act No. 8371. An Act to Recognize, Protect and Promote the Rights of Indigenous Cultural Communities/Indigenous Peoples, Creating a National Commission on Indigenous Peoples, Establishing Implementing Mechanisms, Appropriating Funds Therefor, and for Other Purposes. October 29, 1997.

Resolution 36: News from the restorative justice consortium. (2010). Restorative Justice Consortium, RJC; Restorative Justice Council. Retrieved from http://www.restorativejustice.org.uk/Resources/Newsletters/2010/ Resolution\%2036\%20Summer\%202010.pdf. October 7, 2010.

Restorative Justice. Parole and Probation Administration. Open Data Portal. Retrieved from http://probation.gov.ph/restorative-justice/. August 21, 2018.

Sharpe, S. (1998). Restorative justice: A vision for healing and change. Edmonton, Canada: Mediation and Restorative Justice Centre.

Sherman, L. (1993). Defiance, deterrence and irrelevance: A theory of the criminal sanction. Journal of Research in Crime \& Delinquency, 30, 445-473. https://doi.org/10.1177/0022427893030004006

Sherman, L. W., \& Strang, H. (2007). Restorative justice: The evidence. London: Smith Institute.

Siegel, L. J., \& Senna, J. J. (2007). Essentials of criminal justice. Thomson Wadsworth, University of Massachusetts, Lowell and Northeastern University, Massachusetts.

Termotto, Sr. J. A. (2007). Community peacemaking using restorative justice principles "establishing a culture of harmony in the presence of dissonance." Rochester New York USA. Retrieved from http://www.iirp.edu/pdf/hu07/hu07_termotto.pdf 
The Cordillera: Its land and people (2004). Cordillera Peoples Alliance: For the Defense of the Ancestral Domain and Self-Determination. Retrieved from http://www.cpaphils.org/cordillera.htm.

Victim-offender mediation guidelines for starting a service. Bristol: Mediation UK. (2005). Internet Journal of Criminology IJC. Retrieved from www.internetjournalofcriminology.com.

Walker, L., Sakai, T., \& Brady, K. (2006). Restorative circles - A reentry planning process for Hawaii inmates. Federal Probation, 70(1), IIRP; International Institute for Restorative Practices. Retrieved from http://www.lorennwalker.com/articles/Restorative_Circles-1.pdf

Welsh, W. N., \& Harris, P. W. (2008). Criminal justice: Policy \& planning. Newark, NJ: LexisNexis Group.

Zaibert, L. (2006). Punishment and retribution. Ashgate Publishing.

Zehr, H. (2002). The little book of restorative justice. Intercourse, PA: Good Books.

\section{Copyrights}

Copyright for this article is retained by the author(s), with first publication rights granted to the journal.

This is an open-access article distributed under the terms and conditions of the Creative Commons Attribution license which permits unrestricted use, distribution, and reproduction in any medium, provided the original work is properly cited. 